Article

\title{
Dynamic Analysis of the Similarity of Objects in Research on the Use of Renewable Energy Resources in European Union Countries
}

\author{
Iwona Bąk $^{1}\left(\mathbb{D}\right.$, Anna Spoz ${ }^{2}$, Magdalena Zioło ${ }^{3, *(\mathbb{D})}$ and Marek Dylewski ${ }^{4, * \mathbb{D}}$ \\ 1 Faculty of Economics, West Pomeranian University of Technology, 71-270 Szczecin, Poland; \\ iwona.bak@zut.edu.pl \\ 2 Institute of Economics and Finance, The John Paul II Catholic University of Lublin, 20-950 Lublin, Poland; \\ aspoz@kul.lublin.pl \\ 3 Faculty of Economics, Finance and Management, University of Szczecin, 71-101 Szczecin, Poland \\ 4 Institute of Economics and Finance, WSB University in Poznan, 61-895 Poznan, Poland \\ * Correspondence: magdalena.ziolo@usz.edu.pl (M.Z.); marek.dylewski@wsb.szczecin.pl (M.D.)
}

check for updates

Citation: Bąk, I.; Spoz, A.; Zioło, M.; Dylewski, M. Dynamic Analysis of the Similarity of Objects in Research on the Use of Renewable Energy Resources in European Union Countries. Energies 2021, 14, 3952. https://doi.org/10.3390/en14133952

Academic Editor: Anastasios Dounis

Received: 21 May 2021

Accepted: 27 June 2021

Published: 1 July 2021

Publisher's Note: MDPI stays neutral with regard to jurisdictional claims in published maps and institutional affiliations.

Copyright: (c) 2021 by the authors. Licensee MDPI, Basel, Switzerland. This article is an open access article distributed under the terms and conditions of the Creative Commons Attribution (CC BY) license (https:// creativecommons.org/licenses/by/ $4.0 /)$.

\begin{abstract}
The energy transformation towards renewable energy sources in the conditions of climate change and the accompanying climate risk is a priority for all countries in the world. However, the degree of advancement of activities in this area varies significantly between countries, which is the result of different activities for renewable energy sources in individual countries. The aim of this article is to determine the trends of changes in the area of the use of renewable energy sources in EU countries. The study uses TMD (taxonomic measure of development) methods and dynamic classification, which allowed to distinguish typological groups of objects with similar dynamics of the studied phenomenon. The EU 28 countries were analyzed. Statistics (Eurostat database) are provided for the period 2004-2019. As a result of the research, it was found that the Scandinavian countries and the countries of Western Europe were characterized by the highest stability in terms of the use of renewable energy sources over time. These countries also recorded the smallest increases in TMD. On the other hand, the unfavorable situation in terms of stability was observed mainly in the countries of Southern Europe.
\end{abstract}

Keywords: renewable energy sources; European Union; dynamic classification; trend models; environmental policy

\section{Introduction}

The operation and progress of the linear economy are based mainly on the use of fossil fuels, but these, in the face of the depletion of many deposits, are no longer effective, which makes it necessary to look for them further and further, e.g., in the Arctic. All this makes the production of energy from non-renewable sources increasingly expensive and thus less profitable, and more importantly, causes negative effects not only in environmental matters, but also affects the entire economy and the social sphere. This problem is noticed and widely commented on at the international level. The growing threat of climate change caused by greenhouse gas emissions poses new challenges for modern countries. Energy is essential to the economy as it contributes to production across industries and sectors and impacts sustainable development, including economic activity, society, and the environment. The European Green New Deal focused inter alia on renewable energy is a "roadmap meant to foster the transition of the European Union towards the climate-neutral economy" [1]. Therefore, there is a need for energy saving and energy efficiency [2]. Countries undertake to limit the extraction and use of emission deposits, replacing them with renewable energy sources (RES). Data from the International Renewable Energy Agency IRENA from the end of 2019 indicate that there are installations with a total capacity of $2537 \mathrm{GW}$, which use renewable energy. Thus, the share of renewable energy in total energy increased to $34.7 \%$ 
at the end of 2019. In order to reach the EU climate and energy goals, financing is needed and in this context the perspective of EU funds on renewable energies is crucial [3,4].

The literature on the subject emphasizes that alternative energy sources carry positive values globally and individual units [5-11]. These are sources that, unlike non-renewable energy sources, are non-exhaustive and environmentally friendly. Their dissemination will reduce greenhouse gas emissions, reduce the generation of waste in the energy production process, and probably contribute to increasing energy security worldwide.

In European Union countries, activities promoting renewable energy result largely from the need to achieve the goal set jointly by the Member States. EU countries committed to ensuring a particular share of renewable energy sources in gross final energy consumption in 2020. For the European Community as a whole, this target was $20 \%$. For the next decade, the European Commission has set an increase in the share of renewable energy sources in the mix of produced power to the level of $32 \%$. This goal is to be achieved by 2030. Therefore, the question arises: what is the situation in the EU Member States concerning the use of renewable energy sources, and what is the trend in this respect? The answer to this question is the main subject of research by the authors of this study.

Therefore, the work aims to define the trends of changes in the area of RES use in EU countries and distinguish typological groups of objects (EU countries) with similar dynamics of the studied phenomenon. The research used data from 2004-2019 available in the Eurostat database. Considering time in the conducted research made it possible, thanks to using time series analysis methods, to identify countries where the improvement in RES use can be observed, countries with a constant level, and those for which the situation deteriorates. For the dynamic classification, trend functions were used, determined based on the synthetic measures of development. They were established using the zero unitarization method, and their parameters and the theoretical values of the variables constitute the basis for the classification of countries. The calculated aggregate measure, i.e., the taxonomic measure of development (TMD), allows for an unambiguous assessment of the EU countries due to the application of renewable energy sources (RES) in a static manner, i.e., on its basis only the positions of objects (EU countries) in individual years can be determined. In a situation where we are interested in answering the question what is the trend of changes in individual EU countries in the area of RES use in the entire period under study, i.e., in the years 2004-2019, the designated aggregate measures are insufficient. Due to the above, it was decided to estimate the trend models in which the TMD values were adopted as the dependent variable. The coefficients of the trend models provide additional information on level of changes in the studied area. On their basis, it is possible to evaluate the EU countries in terms of the level of dynamics of the use of RES and distinguish typological groups of objects with similar dynamic of changes in the level of the studied phenomenon, as well as the level of random fluctuations. Thanks to this approach, it is possible to assess whether or not EU countries are making progress in the use of renewable energy sources, as was done in this article.

The applied methods allow for detecting several structural and dynamic regularities that cannot be captured by methods using multidimensional statistical analyses in a static approach. Only a comparative analysis carried out in a sufficiently broad period allows for an objective capturing of relationships between various objects. The authors' suggestions presented in this article concern the dynamic analysis of the similarity of objects (EU countries), i.e., the identification of change trends in the field of renewable energy sources in individual European Union countries and the separation of typological groups of objects (EU countries) with similar dynamics of the studied phenomenon. This type of approach was used for the first time in this study, and thus it fills the existing research gap in research related to the dynamic similarity analysis of socio-economic objects (EU countries). 


\section{Literature Review}

Economic and social development boosts the demand for energy [12]. The increased interest in alternative, that is, renewable energy sources, first emerged in late 1990s and was driven by a crisis triggered by the rise in oil prices, which, in addition to severe financial consequences, also revealed the dependence of economies on fossil fuels [13]. To expand the share of renewable energy sources in the energy mix can be a solution to this problem, as these are inexhaustible. The focus on renewable energy sources is also due to the growing awareness of anthropogenic effects on the natural environment and the need to protect it [14]. Therefore, it fits well in the concept of sustainable development [15]. Renewable energy sources generate a minimum amount of process waste [6] and contribute to reducing greenhouse gas emissions, and thus preventing climate change [16]. As Gielen et al. [17] show in their study, renewable energy combined with end-use electrification can deliver up to $94 \%$ emission reductions. Better energy security and reduced risks may be obtained by diversification of energy sources [18].

The environmental impact of individual countries depends on their degree of industrialization. According to Elum et al. [19] and Ziolo et al. [20], developed countries cause the most greenhouse gas emissions. Therefore, it is important to plan and realize the transition to renewable energy on a national basis.

Initiatives taken at the national level must be consistent with the energy strategy of the country and, in the case of Member States, match with the objectives adopted by the European Union, which plans to reduce greenhouse gas emissions by $20 \%$ by 2030 and increase the share of renewable energy in the final energy consumption within the EU up to $20 \%$ [21]. Among 18 European countries included in the research conducted by Wang and Zhan [22], Germany, France, the UK, and Italy have the best sustainability of renewable energy. The researchers identified indicators with a significant impact on the renewable energy sustainability, which are energy taxes, energy demand, and emissions of carbon dioxide, sulfur oxides, and nitrous oxides. It was also shown that the sustainability level continues to increase.

Jenniches pointed that [23] the options for use of renewable energy sources should be analyzed from a regional point of view. The author justifies this approach by the fact that the available options and efficiencies of energy sourcing depend on natural conditions, which vary by region of the same country. For example, the best renewable energy source in China is hydropower. Considering individual regions, it can be seen that the North and Northeast China are geared towards wind energy, Central South and Southwest China towards hydropower, and solar energy is the domain of East and Northwest China. A sensitivity analysis conducted by Li et al. [24] (2020) shows that the sensitivity of energy efficiency, its variability, and economic allocation are relatively high. These dependencies are also valid for Poland. According to Statistics Poland [25], in Poland, in 2019, the region with the highest energy output from renewable sources is the Kuyavian-Pomeranian Province. The Opolskie Province ranked the last in terms of RES energy production.

The development of renewable energy technology has several limitations. Solangi et al. [26] identifies the main types of barriers of this development as "Political \& Policy," "Economic \& Financial," and "Market". Fortunately, they also revealed that "Capital Subsidies," "Feed-in Tariffs," and "Direct, Enabling, \& Integrating Policies," help to overcome the barriers and implement technologies of renewable energy.

In order to encourage investments in renewable energy sources, systems of incentives and reliefs are introduced. These systems and relief schemes differ depending on the country [27], from tax cuts in Belgium to investment relief in the U.S. or tax deductions in Ireland. The scope of application of the incentives also varies. For example, Belgium's tax cut has covered all technologies, while China has only applied this instrument to solar, wind, and geothermal energy. Lopez-Lezama et al. [28] demonstrated in their study that the application of an investment relief and accelerated depreciation schemes brings the levelized cost of electricity down by $20 \%$. Further, Simsek and Simsek [29] showed that the use of incentives such as an exemption from license fees for up to eight years, followed 
by a limitation of their amount, a reduction in the licensing burdens, an obligation on distributors to purchase a share of energy from renewable sources, and lowering the fees for project feasibility and preparatory studies and purchase of land for investment projects to $85 \%$ have boosted investment in renewable energy projects in Turkey. The United States is an example of a successful transformation of the energy sector towards renewable energy. With a strong federal and state-level policy, supported by a tax incentive program, renewable energy sources covered $11 \%$ of total demand and accounted for $17 \%$ of total U.S. electricity production in 2019 [30].

Renewable energy sources, due to the fact that they cover five main types of energy (solar, wind, geothermal, hydro, biomass and biogas), are an extremely wide and multidimensional field of study. Pan and Wang [31] pointed out that each type of renewable energy has its own characteristics and related risks, which should be carefully analyzed by all stakeholders before making a decision to invest in a project.

A review of the current research directions in the field of types of renewable energy is presented in Table 1.

Table 1. Research directions in the field of types of renewable energy.

\begin{tabular}{|c|c|c|}
\hline Renewable Energy Type & Directions of Research & Authors \\
\hline Solar energy & $\begin{array}{l}\text { positive relationship between solar energy and } \\
\text { installation size } \\
\text { the possibility of using solar energy and the } \\
\text { amount of energy that can be generated } \\
\text { cost of installation, generation, and cost } \\
\text { effectiveness } \\
\text { impact on environment }\end{array}$ & $\begin{array}{c}\text { John et al. (2021) [32], Cousse (2021) [33] } \\
\text { Chiemelu et al. (2021) [34] } \\
\text { Yao et al. (2021) [35], Farnè et al. (2021) [36], } \\
\text { Hamzaoğlu et al. (2021) [37], Anctil et al. (2019) } \\
\text { [38], Sultan et al. (2018) [39], Novacheck and } \\
\text { Johnson (2015) [40] } \\
\text { Shahsavari and Akbari (2018) [41], Novacheck } \\
\text { and Johnson (2015) [41], Creutzig et al. (2017) } \\
\text { [42] }\end{array}$ \\
\hline Wind energy & $\begin{array}{l}\text { cost of installation, generation and cost } \\
\text { effectiveness } \\
\text { impact on environment } \\
\text { barriers and incentives for installation or } \\
\text { improvement of wind energy }\end{array}$ & $\begin{array}{c}\text { Yao et al. (2021) [35], Ambec and Crampes } \\
\text { (2019) [43], Adeyeye et al. (2020) [44] } \\
\text { Sayed et al. (2020) [45], Wellig et al. (2018) [46]) } \\
\text { Diógenes et al. (2020) [47], Gönül et al. (2021) } \\
\text { [48], Aldy et al. (2018) [49], Black et al. (2014) } \\
\text { [50] }\end{array}$ \\
\hline Hydro energy & $\begin{array}{l}\text { cost of installation, generation, and cost } \\
\text { effectiveness } \\
\text { environmental impact } \\
\text { incentives and barriers for installation or } \\
\text { improvement of hydro energy }\end{array}$ & $\begin{array}{l}\text { Yao et al. (2021) [35], Javed et al. (2019) [51], } \\
\text { Fan et al. (2020) [52] } \\
\text { Sayed et al. (2020) [45], Lu et al. (2019) [53] } \\
\text { Penghao et al. (2018) [54], Yang et al. (2011) } \\
\text { [55], Ciric (2019) [56] }\end{array}$ \\
\hline Geothermal energy & $\begin{array}{l}\text { cost of installation, generation, and cost } \\
\text { effectiveness } \\
\text { mitigate climate change and sustainable } \\
\text { development } \\
\text { barriers and incentives for installation or } \\
\text { improvement }\end{array}$ & $\begin{array}{l}\text { Yao et al. (2021) [35], Farnè et al. (2021) [36] } \\
\text { Paulillo et al. (2019) [57], Bošnjakovid et al. } \\
\text { (2019) [58], Shortall et al. (2015) [59], Sayed } \\
\text { et al. (2020) [45] } \\
\text { Yasukawa et al. (2020) [60] }\end{array}$ \\
\hline Biomass energy & $\begin{array}{c}\text { environmental impact and sustainable } \\
\text { development } \\
\text { cost of installation, generation, and cost } \\
\text { effectiveness }\end{array}$ & $\begin{array}{c}\text { Danish and Ulucak (2019) [61], Güney and } \\
\text { Kantar (2020) [62], Sayed et al. (2020) [45], } \\
\text { Chang et al. (2017) [63]) } \\
\text { Inayat et al. (2019) [64], Mohamed et al. (2017) } \\
\text { [65] }\end{array}$ \\
\hline
\end{tabular}

Qazi et al. [66] pointed out that one of the factors hindering the spread of renewable energy is a low level of social awareness, and proposed a remedy in the form of educational programs and curricula related to renewable energy. An argument in favor of this solution can come from the results of a study by Yang et al. [67], who demonstrated that consumers 
are generally willing to pay extra for a growing share of renewable energy, but prefer to continue cooperation with their existing energy supplier.

\section{Data and Methodology}

The main purpose of the research presented in the paper is to identify the trends of changes in the area of RES use in individual European Union countries and distinguish typological groups of objects (EU countries) with similar dynamics of the studied phenomenon. The research procedure consisted of the following stages.

1. Building a database on the use of renewable energy. The article uses the following indicators provided by Eurostat. $X_{1}$-Overall share of energy from renewable sources $X_{2}$-Share of energy from renewable sources in gross electricity consumption $X_{3}-$ Share of energy from renewable sources in transport $X_{4}$-Share of energy from renewable sources for heating and cooling $X_{5}$-Electricity generation per capita $(\mathrm{kWh})$-Hydro $X_{6}$-Electricity generation per capita $(\mathrm{kWh})$-Wind $X_{7}$-Electricity generation per capita $(\mathrm{kWh})$-Solar $X_{8}$-Electricity generation per capita $(\mathrm{kWh})$ Solid biofuels $X_{9}$-Electricity generation per capita $(\mathrm{kWh})$-All other renewables $X_{10}$ Electricity generation per capita $(\mathrm{kWh})$-Total (RES-E numerator) $X_{11}$-Transport per capita $(\mathrm{kWh})$ - Ren. electricity in road transport $X_{12}$ - Transport per capita $(\mathrm{kWh})$ Ren. electricity in rail transport $X_{13}$ - Transport per capita $(\mathrm{kWh})$ - Ren. electricity in all other transport modes $X_{14}$ - Transport per capita $(\mathrm{kWh})$-Compliant biofuels $X_{15}$-Transport per capita (kWh) - Total (RES-T numerator with multiplicators) $X_{16}$ Heating and cooling per capita $(\mathrm{kWh})$-Final energy consumption $X_{17}$ - Heating and cooling per capita $(\mathrm{kWh})$-Derived heat $\mathrm{X}_{18}$ - Heating and cooling per capita $(\mathrm{kWh})$ - Heat pumps $X_{19}$ - Heating and cooling per capita $(\mathrm{kWh})$ - Total (RES-H\&C numerator)

2. Determining the distribution of diagnostic features

All indicators adopted for the study are stimulants, i.e., features that positively impact the studied phenomenon. On their basis, taxonomic measures of development will be constructed. These synthetic variables replace the description of research objects using diagnostic features with a description using one aggregate quantity [68-71]. Pattern and non-pattern measures are used for that purpose. The difference between them is that the structure of the measure of the latter type has a specific reference point against which this level of development will be determined. On the other hand, in the methods that do not use the development pattern, the synthetic measure is only a particular function of standardized diagnostic features. One of the most frequently used methods, in this case, is the zero unitarization method used in this paper.

The choice of synthetic measure is also influenced by order of the diagnostic features adopted for the study. It should be noted that the preliminary analysis of the characteristics indicates considerable disproportions in the field of RES between the studied countries (Table 2). This is indicated by high values of the coefficient of variation $\left(V_{S}\right)$ and the coefficient of skewness measures $(A)$. The first of these parameters ranges from 53.56 to $325 \%$, whereas in seven features, the measure of differentiation exceeds $100 \%$. Moreover, all indicators show a strong or strong right-sided asymmetry, which means that the values of the features are below the average value for most EU countries, which is unfavorable in the case of features defined as stimulants. Considering the above, it was decided to use the method of zero unitarization described below to classify the EU countries. 
Table 2. Selected descriptive parameters for diagnostic features.

\begin{tabular}{ccccc}
\hline Symbol & $\overline{\boldsymbol{x}}$ & $\mathbf{M}$ & $\boldsymbol{V}_{\boldsymbol{S}}$ & $\boldsymbol{A}$ \\
\hline$X_{1}$ & 0.22 & 0.18 & 53.56 & 1.13 \\
$X_{2}$ & 0.33 & 0.32 & 56.65 & 0.75 \\
$X_{3}$ & 0.09 & 0.08 & 59.51 & 3.01 \\
$X_{4}$ & 0.29 & 0.26 & 57.10 & 0.53 \\
$X_{5}$ & 952.45 & 361.28 & 156.40 & 2.59 \\
$X_{6}$ & 692.45 & 477.74 & 97.26 & 1.48 \\
$X_{7}$ & 188.27 & 173.94 & 77.17 & 0.73 \\
$X_{8}$ & 317.02 & 175.32 & 143.38 & 3.06 \\
$X_{9}$ & 132.80 & 103.21 & 81.50 & 1.44 \\
$X_{10}$ & 2282.98 & 1674.57 & 88.94 & 2.41 \\
$X_{11}$ & 2.98 & 1.44 & 136.43 & 2.31 \\
$X_{12}$ & 36.40 & 27.10 & 105.70 & 2.38 \\
$X_{13}$ & 6.07 & 0.37 & 325.00 & 4.61 \\
$X_{14}$ & 479.49 & 323.17 & 96.83 & 2.25 \\
$X_{15}$ & 750.76 & 561.81 & 87.08 & 2.77 \\
$X_{16}$ & 2537.78 & 1919.25 & 91.11 & 1.55 \\
$X_{17}$ & 849.23 & 253.68 & 146.74 & 2.05 \\
$X_{18}$ & 330.93 & 195.19 & 109.27 & 2.31 \\
$X_{19}$ & 3717.94 & 2353.66 & 95.59 & \\
\hline
\end{tabular}

3. Construction of taxonomic measures of development using the zero unitarization method [72].

This method uses the following transformations:

for stimulant:

$$
z_{i j}=\frac{x_{i j}-\min _{i} x_{i j}}{\max _{i} x_{i j}-\operatorname{minx}_{i}}, \text { where } \operatorname{maxx}_{i} \neq \operatorname{minx}_{i}
$$

for destimulant:

$$
z_{i j}=\frac{\operatorname{maxx}_{i j}-x_{i j}}{\max _{i} x_{i j}-\operatorname{minx}_{i}}, \text { where } \max _{i} x_{i j} \neq \min _{i} x_{i j}
$$

Such a normalization method causes all values of the normalized features to fall within the range $[0,1]$. The synthetic measure of development $z_{i}$ is built as the arithmetic mean of the standardized values of diagnostic features:

$$
Z_{i}=\frac{1}{K} \sum_{k=1}^{K} z_{i k}^{t}
$$

where: $K$-the number of diagnostic features.

4. Dynamic classification based on the trend functions of taxonomic measures of development (TMD) [73,74].

Dynamic multivariate comparative analysis deals with the statistical analysis of data presented in the form of a three-dimensional matrix [75]:

$$
X=\left[x_{i j t}\right] \quad(i=1, \ldots, n ; j=1, \ldots, m ; t=1, \ldots, k),
$$

where, $i$ is the number of objects, $\mathrm{m}$-the number of diagnostic features, and $\mathrm{k}$ is the number of moments (periods) of time included in the research.

Synthetic measures of development allow for the reduction of the initial observation $\mathrm{X}$ matrix with dimensions of $\mathrm{n} X \mathrm{mXk}$ to a two-dimensional matrix $\mathrm{nXk}$ containing for each object realization of synthetic variables in the form of k-element time series. These series 
can be used to estimate the parameters of the first, second, and third-degree linear and exponential development trend models:

$$
\begin{gathered}
\hat{Y}_{t}=\hat{\alpha}_{1} t+\hat{\alpha}_{o} \\
\ln \hat{Y}_{t}=\hat{\alpha}_{1} t+\hat{\alpha}_{o} \\
\hat{Y}_{t}=\hat{\alpha}_{1} t+\alpha_{2} t^{2}+\hat{\alpha}_{o} \\
\ln \hat{Y}_{t}=\hat{\alpha}_{1} t+\alpha_{2} t^{2}+\hat{\alpha}_{o} \\
\hat{Y}_{t}=\hat{\alpha}_{1} t+\alpha_{2} t^{2}+\alpha_{3} t^{3}+\hat{\alpha}_{o} \\
\ln \hat{Y}_{t}=\hat{\alpha}_{1} t+\alpha_{2} t^{2}+\alpha_{3} t^{3}+\hat{\alpha}_{o}
\end{gathered}
$$

Identifying typological groups of objects with a similar level of dynamics of the studied phenomenon is based on a sequence containing the respective trend coefficients' values according to non-increasing values. In individual typological groups, there are objects with the values of the development measure from the following ranges [76]:

$$
\begin{aligned}
& \text { group 1: } Z_{i} \geq \bar{Z}+S_{z}, \\
& \text { group 2: } \bar{Z}+S_{z}>Z_{i} \geq \bar{Z}, \\
& \text { group 3: } \bar{Z}>Z_{i} \geq \bar{Z}-S_{z}, \\
& \text { group 4: } Z_{i}<\bar{Z}-S_{z} .
\end{aligned}
$$

5. Dynamic classification based on random fluctuations of taxonomic measures of development

In the dynamic classification of the studied phenomenon, much information is obtained by comparing TMD random fluctuations in the classified objects. The measure of the intensity of random fluctuations in the interval $[1, T]$ is the coefficient of random variation of the taxonomic trends of the development measures of the compared objects:

$$
w_{i}=\frac{s_{e_{i}}}{\bar{z}_{i}}
$$

where $\bar{z}_{i}$ is the arithmetic mean of the development measure of the object $O_{i}$ in the time interval $[1, T], s_{e_{i}}$ the standard deviation of the remaining trend of the development measure of the i-th object:

$$
s_{e_{i}}=\sqrt{\frac{1}{T} \sum_{t=1}^{T}\left(e_{i t}-\bar{e}_{i}\right)^{2}}
$$

and $e_{i t}$ denote the rest of the trend of the taxonomic development measure of the $i$-th object, i.e., the deviations of the actual values of $Z_{i t}$ of this measure from its theoretical values of $\hat{Z}_{i t}$ determined according to the trend equation. Higher values of the $w_{i}$ coefficient indicate more significant random fluctuations in time in the level of the studied phenomenon. This coefficient can be the basis for selecting groups of objects with a similar range of TMD random fluctuations, such a classification of objects is used to assess the stability of the analyzed phenomenon over time.

\section{Results}

Tables A1 and A2 present the results of EU countries' classification obtained based on the value of the synthetic measure of development calculated based on the features characterizing the use of renewable energy sources. As can be seen, the positions taken by individual EU countries in the obtained rankings were, in most cases, different. Considering the beginning and the end of the analyzed period, only five countries (Cyprus, Hungary, Italy, Portugal, Sweden) did not change their positions in the analyzed years, which does not mean that their positions in the ranking were stable the whole period. Such stability 
was observed only in Sweden, ranked first in each ranking, and Cyprus, which, apart from two years (2016 and 2018), was in the penultimate position in the rankings. It is worth noting that only thirteen Member States saw an improvement in RES's situation in 2019 compared to 2004. Ten countries recorded a drop in the ranking during this period, with the highest for France and Slovenia (down by 9 places), Croatia (down by 7 places), and Poland and Slovakia (down by 6 places).

In 2004-2019, Sweden was the highest, followed by Austria and Finland alternately. In four countries (Denmark, Latvia, Malta, Germany), the differences in the rankings ranged from one to three positions. The most significant discrepancy in the rankings was noticed for Bulgaria, which in 2004 was the nineteenth place, three years later improved by sixteen places, in 2008 it fell by seven places, and in 2019 it moved up to the eleventh place.

Because the rankings of countries in the analyzed years are not the same, and in some cases, they differ significantly, the Kendall tau correlation coefficients were determined (Table A3). They assume values in the range $[-1,1]$ and assess the degree to which the order of the examined objects is consistent. The closer the coefficient value is to one, the greater the agreement of the orderings is $[77,78]$. As shown in Table A3, the high values of the coefficients prove that the linear ordering of countries is quite consistent, even though there are discrepancies in the positions taken by some objects. The highest value of the correlation coefficient was obtained for the rankings in 2016 and 2017, and the lowest for 2010 and 2019.

In the further part of the work, the taxonomic measures of development from 2004 2019 were used to determine the trends of changes in RES use in the EU and distinguish typological groups of objects (EU countries) with similar dynamics of the studied phenomenon. The trend functions determined according to taxonomic (synthetic) measures of development based on the zero unitarization method were used for the dynamic classification. It turned out that the best results in terms of the degree of fit to empirical data and the significance of parameter estimates were obtained with the use of first-degree linear and exponential models. These models were used in the dynamic classification.

The measure of the average increase of the taxonomic measure of the $i$-th object is the parameter $b_{i}$ of the linear trend:

$$
\hat{Z}_{i}=a_{i}+b_{i} t
$$

The measure of the average rate of change is the size of:

$$
c_{i}=C_{i}-1
$$

where $C_{\text {and }}$ is the exponential trend parameter:

$$
\hat{Z}_{i}=d_{i} C_{i}^{t}
$$

The parameters $b_{i}$ of the linear trend and $c_{i}$ of the exponential trend were used to construct the rankings, but the trend parameters were previously transformed so that the obtained synthetic measures were within the range [0,1]. For this purpose, the following transformations are used:

$$
\begin{gathered}
b_{i}^{\prime}=g b_{i}-\min _{i} b_{i}, b_{i}^{\prime \prime}=\frac{g b_{i}^{\prime}}{\max _{i}^{\prime \prime}}, i=1, \ldots, n \\
c_{i}^{\prime}=c_{i}-\operatorname{minc}_{i}, c_{i}^{\prime \prime}=\frac{c_{i}^{\prime}}{\max _{i}^{\prime}}, i=1, \ldots, n
\end{gathered}
$$

In the next stage of the research, the coefficients of random variation of trends in taxonomic development measures (formula 12) were determined, which were used to organize the EU countries in terms of RES stability. However, it should be remembered that objects with lower values of the coefficient are more stable. The results of the rankings 
obtained based on linear and exponential trends and the random fluctuation coefficient are presented in Table 3 and Figures A1-A4.

The highest average absolute increases in taxonomic measures of development and relative increases concerned the countries in the first group. High compliance is seen in the following countries: Belgium, Bulgaria, and Greece. In these countries, the TMD values grew by an average of approx. 0.008 TMD values, i.e., by $8 \%$, from year to year. In terms of the dynamics of the analyzed phenomenon, the highest similarity applies to the countries in the fourth group. A slight dynamic of the phenomenon characterizes the objects from this group. Malta deserves attention, which due to the value of TMD was at the end of the rankings in 2004-2017, and in the following years, it was ranked third or third from the end. The dynamic analysis shows that in this country in the analyzed period, TMD increased by an average of $9.89 \%$ year by year, which placed this country in the 8th position regarding the absolute increase and in the first due to the average pace of changes, which indicates that the country's situation is improving due to RES.

Valuable information is also obtained from a comparative analysis of random fluctuations of taxonomic development measures of the studied phenomenon in the classified objects. Larger values of the coefficient $w_{i}$ indicate greater random fluctuations in time in the level of the studied phenomenon [76]. In addition, this coefficient can be used to separate groups of objects (countries) with a similar range of random fluctuations of a taxonomic measure, similar to indicators $b_{i}$ and $c_{i}$. As shown in Table 1, the orderings of the EU countries based on random fluctuations determined based on first-degree linear and exponential trends are very similar. The distinguished typological groups of countries are also similar. Only in the case of six objects, shifts to adjacent classes are noticeable. Malta demonstrated the highest level of random fluctuations in the years 2004-2019, and in Sweden, it was the lowest, which in the entire analyzed period was at the forefront of rankings related to the use of renewable energy sources.

Table 3. Position in the rank of EU countries for using renewable energy sources in 2004-2019.

\begin{tabular}{|c|c|c|c|c|c|c|c|}
\hline Country & $b_{i}$ & Country & $c_{i}$ & Country & $\begin{array}{c}w_{i} \\
\text { on the Basis } \\
\text { of Linear } \\
\text { Trends }\end{array}$ & $\begin{array}{c}\text { Country } \\
\text { on the Basis of } \\
\text { Exponential } \\
\text { Trends }\end{array}$ & $w_{i}$ \\
\hline Finland & 1.000 & Malta & 1.000 & Malta & 0.355 & Malta & 2.357 \\
\hline Denmark & 0.945 & Cyprus & 0.984 & Hungary & 0.224 & Belgium & 0.261 \\
\hline Estonia & 0.855 & Belgium & 0.890 & Poland & 0.21 & Cyprus & 0.246 \\
\hline Belgium & 0.792 & United Kingdom & 0.80 & Belgium & 90.203 & Hungary & 0.242 \\
\hline Bulgaria & 0.777 & Ireland & 90.791 & Cyprus & 0.198 & Poland & 0.223 \\
\hline Czechia & 0.737 & Bulgaria & 0.781 & Spain & 0.167 & Czechia & 0.201 \\
\hline Greece & 0.728 & Greece & 0.756 & Czechia & 0.164 & Ireland & 0.176 \\
\hline Malta & 0.722 & Czechia & 0.643 & \multirow{7}{*}{$\begin{array}{c}\text { United Kingdom } \\
\text { Netherlands } \\
\text { Bulgaria } \\
\text { Italy } \\
\text { Ireland } \\
\text { France }\end{array}$} & \multirow{7}{*}{$\begin{array}{l}0.151 \\
0.135 \\
0.134 \\
0.133 \\
0.123 \\
0.120\end{array}$} & Spain & 0.172 \\
\hline Italy & 0.721 & Estonia & 0.582 & & & Italy & 0.150 \\
\hline United Kingdom & 0.687 & Netherlands & 0.472 & & & Luxembourg & 0.130 \\
\hline Ireland & 0.642 & Italy & 0.43 & & & Netherlands & 0.12 \\
\hline Luxembourg & 0.632 & Lithuania & 90.406 & & & United Kingdom & 90.126 \\
\hline Lithuania & 0.600 & Luxembourg & 0.398 & & & France & 0.124 \\
\hline Netherlands & 0.589 & Hungary & 0.385 & & & Estonia & 0.117 \\
\hline \multirow{8}{*}{$\begin{array}{l}\text { Portugal } \\
\text { Cyprus } \\
\text { Romania } \\
\text { Slovakia } \\
\text { Germany } \\
\text { Hungary } \\
\text { France }\end{array}$} & \multirow{8}{*}{$\begin{array}{c}0.575 \\
0.565 \\
0.45 \\
90.448 \\
0.418 \\
0.411 \\
0.387\end{array}$} & \multirow{8}{*}{$\begin{array}{l}\text { Denmark } \\
\text { Slovakia } \\
\text { Finland } \\
\text { Portugal } \\
\text { Romania } \\
\text { Spain } \\
\text { France }\end{array}$} & \multirow{8}{*}{$\begin{array}{l}0.380 \\
0.340 \\
0.307 \\
0.298 \\
0.285 \\
0.205 \\
0.194\end{array}$} & Luxembourg & 0.113 & Bulgaria & 0.1144 \\
\hline & & & & Portugal & 0.111 & Slovakia & 0.1142 \\
\hline & & & & Slovakia & 0.107 & Portugal & 0.1140 \\
\hline & & & & Estonia & 0.102 & Greece & 0.101 \\
\hline & & & & Greece & 0.098 & Germany & 0.096 \\
\hline & & & & Germany & 0.095 & Lithuania & 0.091 \\
\hline & & & & Lithuania & 0.085 & Slovenia & 0.077 \\
\hline & & & & $\begin{array}{l}\text { Lithuania } \\
\text { Slovenia }\end{array}$ & $\begin{array}{l}0.085 \\
0.077\end{array}$ & Finland & 0.076 \\
\hline
\end{tabular}


Table 3. Cont.

\begin{tabular}{|c|c|c|c|c|c|c|c|}
\hline Country & $b_{i}$ & Country & $c_{i}$ & Country & $\begin{array}{c}w_{i} \\
\text { on the Basis } \\
\text { of Linear } \\
\text { Trends }\end{array}$ & $\begin{array}{c}\text { Country } \\
\text { on the Basis of } \\
\text { Exponential } \\
\text { Trends }\end{array}$ & $w_{i}$ \\
\hline Spain & 0.383 & Germany & 0.182 & Finland & 0.076 & \multirow{7}{*}{$\begin{array}{c}\text { Romania } \\
\text { Austria } \\
\text { Latvia } \\
\text { Croatia } \\
\text { Denmark } \\
\text { Sweden }\end{array}$} & \multirow{7}{*}{$\begin{array}{l}0.074 \\
0.065 \\
0.056 \\
0.044 \\
0.040 \\
0.026\end{array}$} \\
\hline Latvia & 0.356 & Poland & 0.181 & Romania & 0.075 & & \\
\hline Poland & 0.310 & Latvia & 0.122 & Austria & 0.065 & & \\
\hline Croatia & 0.296 & Croatia & 0.107 & Latvia & 0.056 & & \\
\hline Sweden & 0.267 & Sweden & 0.077 & Denmark & 0.046 & & \\
\hline Slovenia & 0.262 & Slovenia & 0.074 & Croatia & 0.044 & & \\
\hline Austria & 0.000 & Austria & 0.000 & Sweden & 0.026 & & \\
\hline
\end{tabular}

Source: own calculations, where $w_{i}$ is the coefficient of random variation of taxonomic trends.

\section{Discussion}

The presented research results make it necessary to consider not only the rate of growth in the use of renewable energy in the EU member states. It is necessary to consider what causes changes in the area of RES use in EU countries and the emergence of typological groups of objects (EU countries) with similar dynamics of the studied phenome-non. In the literature on the subject, you can find a number of analyses that allow you to search for answers to the indicated problem.

Taking into account the changes in the area of RES use in EU countries, it should be noted that the levels of investment in the EU-28 concerning renewable energy are changing and constantly growing. Governments and companies around the world have com-mitted to adding some 826 gigawatts of new non-hydro renewable power capacity in the decade to 2030 [79]. This commitment will cost, and is estimated to be of around USD 1 trillion. Unfortunately, the estimated expenditure is slightly slower than in 2010-2019. This pace in the indicated decade was estimated at USD 2.7 trillion [79]. The COVID-19 crisis has slowed down capital expenditure. However, governments now have the chance to tailor their economic recovery programs and increase the dynamics of investments in renewable energy sources [79].

Our research will show that initiatives taken at the national level result in changes in the energy strategy of the country and, in the case of Member States, match with the objectives adopted by the European Union. Our research will show that initiatives taken at the national level result in changes in the energy strategy of the country and, in the case of Member States, match with the objectives adopted by the European Union. We have shown that thirteen Member States saw an improvement in RES's situation in 2019 compared to 2004. We recognize that five countries (Cyprus, Hungary, Italy, Portugal, Sweden) are working hard to maintain their positions in the analyzed years, which does not mean that their positions in the ranking were stable the whole period. It can be concluded that government policy of these five countries with regard to RES is effective and the society accepts the directions of government intervention aimed at increasing the share of RES in energy consumption and reducing $\mathrm{CO}_{2}$.

We also wondered if the target set by the EU, which plans to reduce greenhouse gas emissions by $20 \%$ by 2030 and increase the share of renewable energy in the final energy consumption within the EU up to $20 \%$ [20] would be realistic in all the countries surveyed. This conclusion came to us after analyzing the results of research on France, Slovenia, Croatia, Poland, and Slovakia. This countries recorded a drop in the ranking during this period, with the highest for France and Slovenia (down by 9 places), Croatia (down by 7 places), and Poland and Slovakia (down by 6 places). Given France's strength and status as a highly developed country, the decline is worrying. In Poland, the government policy focused on the "coal" economy contributed to the decline in the ranking. Such a strong decline in the ranking of Croatia and Slovenia should be seen in the impact of the financial crisis, which shook the countries that do not have a stable position (and the indicated 
countries belong to post-communist countries striving to build a strong position of a developed country). However, the reasons for the decline should be carefully analyzed in the systems of individual member states. Through its policy and approach to financing in the EU countries, this goal seems realistic, but it will definitely be hard to achieve. However, without appropriate policy and funding sources, EU countries may not achieve this goal.

Research indicated in the literature shows that there is the influence of incentive programs and tax relief schemes on the scale of investment in renewable energy sources [27]. We did not study the incentive system, but our research shows the effects of their application in terms of changes in the area of RES use in EU countries, as well as changes in the typological of objects (EU countries) groups distinguished with similar dynamics of the studied phenomenon. The identification of typological groups of objects with a similar level of dynamics of the studied phenomenon (as shown in Table 3) shows how effectively the situation in the field of RES has changed in the analyzed countries, which corresponds to the effectiveness of the policy pursued by the governments of the EU Member States in the field of RES, and indicates the effectiveness of interventions the EU has done itself in this regard. These changes should be seen in the policies of the EU itself, the policies of the governments of the Member States, and the use of appropriate instruments and tools (including financial) stimulating changes towards RES.

Valuable information is also obtained from a comparative analysis of random fluctuations of taxonomic development measures of the studied phenomenon in the classified objects. In countries such as Malta, Belgium, Cyprus, Hungary, Poland, Czechia, and Ireland there are greater random fluctuations in time in the level of the analyzed phenomenon. In other countries, fluctuations are not as high as in the group indicated.

The development of RES and changes in renewable energy use are discussed in the subject through the prism of four key determinants. Belonging to them are:

- political factors, as EU countries recognize energy changes towards RES as a priority development of their countries [20,80-82];

- legal factors, it is necessary to create a stable legal framework for changing Co2 emissions and directing energy production to RES. In the case of EU countries, the legal framework for the operation of the RES sector has long been specified and integrated into the implementation of the SDG's goals [27,83-85];

- geographic (natural) environment, where natural conditions are created for the development of renewable energy sources, and other countries require significant financial outlays for the development of renewable energy sources due to natural shortages [84,86,87];

- financial factor, especially financial outlays, their size and subject of investment [88-90].

These four key determinants are determinants dependent on the policies of the EU itself and its member states. However, to enhance the impact, one must agree with the views of Qazi et al. [66] and Yang et al. [67] and propose to complement the existing measures in favor of the RES. Activities, policies, programs, and tools should be complemented by a strong impact of educational programs and curricula related to renewable energy. We also see the necessity for the governments of the EU countries to create information programs so that the existing energy supplier could inform their customers about the measures taken for the RES [67]. The indicated actions would constitute the fifth key determinants of RES development in the EU countries.

Our research complements the five key determinants indicated above:

- political factors-allows you to check whether there have been changes in the policies that support the development of RES use, including assessing their effectiveness;

- legal factors-allows you to introduce changes aimed at increasing the effectiveness of activities, including policies;

- geographic (natural) environment-allows you to monitor efficiency in the indicated groups, assess the jump of changes and the direction of change of groups in which we classified the countries;

- financial factor-allows to assess whether the level of financing policies was adequate; 
- information and education factor-reflects the need to finance the information policy, promotion activities, and sharing good practices, including the effectiveness of reporting on ESG factors related to RES.

The literature on the subject also indicates non-financial factors based on ESG and related to innovations $[87,88]$. The indicated factors are fit in with the classification of key determinants presented above. One of the specific non-financial factors is COVID-19. Considering the fact that despite the significant EU investment in the fight against COVID19 , as well as the indicated delay in RES investments, in early 2021, the EU Commission will adopt a new, more ambitious EU strategy for accommodating climate change in order to intensify its security measures against climate change. Investments in RES are at the heart of fighting against climate change and attaining climate neutrality. Significant financial resources are necessary for such a strategy [91].

The literature on the subject shows that in recent years, one might spot positive changes concerning the consumption of energy from renewable sources in the European Union, but these changes vary depending on a country [92,93]. The type of renewable energy used depends on the geographical location and the economic and financial efficiency of each source and our research shows that the leaders in the use of RES have changed over the past decade.

If the environment is to serve future generations and society should have access to air without $\mathrm{CO}_{2}$, humanity must give up dirty fuels in favor of environmentally friendly RES. This, of course, is not the only way to act, but the global community must continue to improve energy efficiency and rational energy management. As our research shows, there are changes in the rate of growth in the use of RES in EU Member States, this allows to raise the importance of earlier studies which show that the global community must act in accordance with the principles of sustainable development [82,94-97]. The principles of sustainable development are among the most durable in the Scandinavian and Western European countries, hence the trend in our research is visible.

The interest and importance of the RES has changed and it can be said that this is due to two of the 17 SDG's goals and the financing of investments and activities aimed at their implementation. These SDG's goals are the SDG 7, which reads, "ensure access to affordable, reliable sustainable and modern energy for all," and SDG 13, which reads, "take urgent action to combat climate change and its impacts" [98]. Financial outlays for RES are related to efforts to eliminate the negative effects of climate change. As our research has shown, the Scandinavian countries were characterized by the highest stability in the use of renewable energy over time. In these countries, political stability is widely recognized.

The key factor for the development of RES seems to be an appropriate energy policy and financial support for changes. In particular, it is about financing investments that will support low $\mathrm{CO} 2$ emissions. Our research showed that, however, there is a disparity be-tween EU countries, which is influenced by many factors. As is shown in the literature, EU funds in the field of RES have different success rates in Member States EU [99-103].

The political factor is an important factor driving the shift and shift away from traditional energy sources towards RES. The conducted research shows that, in addition to EU funds and policy factors, technology, economic viability, and investor behaviors play an important role in stimulating renewable investment [104]. Moreover, it should be emphasized that policy inconsistencies cause problems for the industry in both the short and long term, and in particular induce additional investment risks [104,105]. In Scandinavian and Western European countries, the issues of sustainability and social responsibility translate into issues of technology, economic viability, and investor behaviors. Post-communist countries require attention to the goals of the SDG's, and especially in Poland from the point of view of achieving goals SDG 7 and SDG 13.

Political support for RES development allows politicians to demonstrate concern for social welfare (in particular, to reduce ESG risk) and to improve environmental conditions. A stable legal framework also guarantees a predictable investment. A clearly de-fined system of political and financial support allows potential investors to make bold moves 
towards increasing the number of green investments in RES. The development of renewable energy is also an excellent bargaining chip in political negotiations. Especially when financial resources are involved.

Taking time into account in the conducted research made it possible, thanks to the possibility of using time series analysis methods, to distinguish countries where an improvement in the use of renewable energy sources can be observed, countries with a constant level, and those for which the situation deteriorates. As with any change, positive and negative, it can result from country-specific factors. Nevertheless, these factors are concentrated around the indicated four groups of four key determinants.

The policy of rebuilding the economies of the EU countries aims at limiting the financial support of old polluting industries and focusing on financing those industries that will be in the area of reducing $\mathrm{CO}_{2}$ emissions and basing their activities on RES [106]. Therefore, it can be indicated that the financing of innovative investments, new policy, and instruments to support RES and changes caused in the economy by COVID-19 in the future may change the map of comparison of the growth rate of RES use in the EU Member States.

Therefore, our research contributes to understanding the current state as well as providing the basis for promoting renewable energy result as an effective motive for taking further action to improve RES utilization. This study of ours also builds on previous research on RES and its impact on SDG and sustainability goals. These studies complement them and show in a new light the changes taking place in EU countries in the use of RES [18-23,28,31]. Our research will allow (us or different researcher) to conduct a comparative analysis and determine how much the situation in the EU member states is improving in the future. Our research can be applied to further the identification of change trends in the field of renewable energy sources in individual European Union countries and to check whether and to what extent the separation of typological groups of EU countries changes (you can compare the results and changes shown in Table 3). This is important in the decision-making process on policy changes for RES, in instruments and in policy funding sources.

In the future, it would be advisable to investigate the impact of the COVID-19 crisis on changes in the use of renewable energy sources in EU countries, and to check whether the separations of typological groups of objects with similar dynamics of the studied phenomenon still remain in these relations.

As already indicated, COVID-19 has an impact on the financing of investments in RES and the development of the use of renewable energy sources in EU countries. We propose in future studies to check whether the financing costs depend on the risks faced by investors, in particular whether the risk related to COVID-19 and ESG had an impact on costs. These studies were confirmed in the literature [105], but without taking into account the COVID-19 factor. The impact of regulatory risk and market risks from long-term contracts also requires research in the future. Research in this direction was conducted by Newbery [107] and also did not include the influence of the COVID-19 factor.

\section{Conclusions}

The problem of renewable energy sources in the context of energy transformation and in the era of climate change is an important research issue. This article attempts to determine the trends of changes in the area of the use of renewable energy sources in EU countries and to distinguish typological groups of objects with a similar dynamic of the studied phenomenon. The study is based on 19 selected indicators from the Eurostat database for the period 2004-2019. The methods of analysis used in the paper (TMR, dynamic classification) made it possible to trace changes in the area under consideration, taking into account nineteen diagnostic features describing RES in the EU countries.

Our study complements the existing research, as it shows the effects of the existing policy towards RES and the use of instruments for its implementation in EU countries. It shows how individual countries reacted, in which EU countries this reaction was abrupt, and in which the effectiveness of additional variables showed a negative trend. Our 
research also prompted us to consider the key determinants of RES development that shape the trends of changes in the area of RES use in EU countries. We believe that typological groups of EU countries with similar dynamics of the studied phenomenon are determined by the five factors indicated.

Based on the determined fluctuation coefficients of random trends in taxonomic development measures, it can be concluded that the Scandinavian countries and the countries of Western Europe demonstrated the highest stability regarding the use of RES over time. These countries also recorded the smallest increases in TMD. Both the Scandinavian countries and the countries of Western Europe have for many years taken and supported actions aimed at increasing the share of renewable energy sources in total energy production. This applies to fiscal incentives and educational activities, and public support programs in subsidies for investments in renewable energy. At the same time, in the indicated groups of countries, the energy transformation is more manageable because these economies are not based on fossil fuels (coal). On the other hand, the unfavorable situation in terms of stability was mainly observed in the countries of Southern Europe. From the point of view of the increase in the synthetic measure, these countries show a growing tendency each year, which may bode well for the future. Conducted research showed that there is a disparity between EU countries, which is influenced by many factors. Each EU member state should look for these disproportions in order to answer the question of how to improve their position in terms of using RES and how to change its policy to make it more effective. Although from the point of view of the increase in the synthetic measure, EU-countries may show a growing tendency, policymakers should analyze these increases over time in relation to the overall macroeconomic situation, but all factors influencing the disproportion should be analyzed together in a given member state.

The multidimensional dynamic comparative analysis used in the research has many advantages. It allows for the determination of the directions and size of changes over time of the considered objects from the point of view of the studied phenomenon. However, the authors are aware that the condition for its effective use is to have extensive empirical databases containing comparable, reliable, and complete statistical information. It appears that the databases of the statistical offices of EU countries do not always provide complete and up-to-date information.

The obtained results can be used in subsequent years to check the directions of observed changes, both from the individual EU Member States and the geographical regions of Europe. This can be the basis for determining the feasibility of forecasts and making economic decisions aimed at sustainable energy sources. We also see that the results obtained can be helpful to decision makers as an informative element for country positioning as well understanding the current state, to which previous decisions have led. Based on our information, you can benchmark the position of countries over time (leading a benchmark over time by repeating research) and show favorable changes, to create the basis for providing the basis for promoting renewable energy result as an effective motive for taking further action to improve RES utilization. In addition, our research can be used to make decisions on the search for factors that prevented countries from changing their position (shown in our ranking), despite the fact that they had a policy conducive to the development of RES. Our research gives the opportunity to deepen and search for answers on the topic of how to improve the situation in a given country by means of changes in the existing policy of a given government of an EU member.

Author Contributions: Conceptualization, I.B.; methodology, I.B.; software, I.B.; validation, I.B.; formal analysis, I.B.; investigation, I.B.; resources, I.B., M.Z., A.S., and M.D.; data curation, I.B.; writing-original draft preparation, I.B., M.Z., A.S., and M.D.; writing—review and editing, I.B., M.Z., A.S., and M.D.; visualization, I.B., M.Z., A.S., and M.D.; supervision, I.B.; project administration, M.D.; funding acquisition, M.D. All authors have read and agreed to the published version of the manuscript.

Funding: This research received no external funding. 
Institutional Review Board Statement: Not applicable.

Informed Consent Statement: Not applicable.

Data Availability Statement: Publicly available datasets were analyzed in this study. This data can be found here: [https:/ / ec.europa.eu/eurostat/web/energy/data/shares] (accessed on 30 June 2021).

Conflicts of Interest: The authors declare no conflict of interest.

\section{Abbreviations}

ESG Environmental Social and Governance

EU European Union

GW GigaWatt

IRENA International Renewable Energy Agency

RES renewable energy sources

SDG Sustainable Development Goals

TMD taxonomic measure of development 


\section{Appendix A}

Table A1. The EU countries sorted by using renewable energy sources in: 2004-2011.

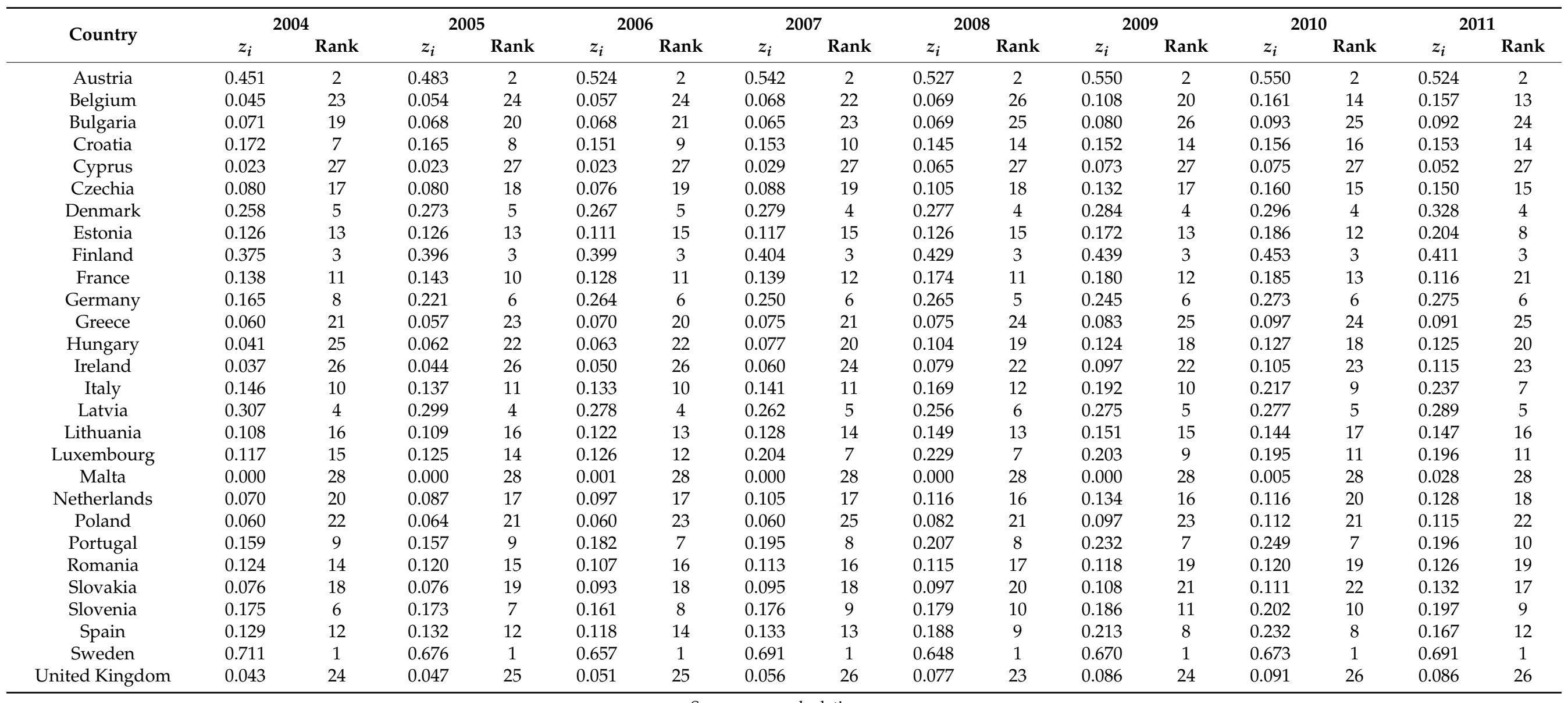

Source: own calculations. 
Table A2. The EU countries sorted by using renewable energy sources in: 2012-2019.

\begin{tabular}{|c|c|c|c|c|c|c|c|c|c|c|c|c|c|c|c|c|}
\hline \multirow{2}{*}{ Country } & \multicolumn{2}{|c|}{2012} & \multicolumn{2}{|c|}{2013} & \multicolumn{2}{|c|}{2014} & \multicolumn{2}{|c|}{2015} & \multicolumn{2}{|c|}{2016} & \multicolumn{2}{|c|}{2017} & \multicolumn{2}{|c|}{2018} & \multicolumn{2}{|c|}{2019} \\
\hline & $z_{i}$ & Rank & $z_{i}$ & Rank & $z_{i}$ & Rank & $z_{i}$ & Rank & $z_{i}$ & Rank & $z_{i}$ & Rank & $z_{i}$ & Rank & $z_{i}$ & Rank \\
\hline Austria & 0.513 & 2 & 0.494 & 3 & 0.481 & 3 & 0.489 & 3 & 0.479 & 3 & 0.470 & 3 & 0.460 & 3 & 0.417 & 3 \\
\hline Belgium & 0.162 & 15 & 0.158 & 17 & 0.146 & 17 & 0.139 & 19 & 0.156 & 17 & 0.161 & 17 & 0.155 & 18 & 0.147 & 21 \\
\hline Bulgaria & 0.105 & 25 & 0.150 & 18 & 0.136 & 19 & 0.147 & 18 & 0.151 & 18 & 0.147 & 20 & 0.144 & 19 & 0.183 & 11 \\
\hline Croatia & 0.154 & 17 & 0.167 & 14 & 0.160 & 14 & 0.168 & 15 & 0.162 & 16 & 0.162 & 16 & 0.164 & 16 & 0.166 & 14 \\
\hline Cyprus & 0.052 & 27 & 0.064 & 27 & 0.071 & 27 & 0.078 & 27 & 0.081 & 26 & 0.083 & 27 & 0.108 & 24 & 0.079 & 27 \\
\hline Czechia & 0.189 & 11 & 0.186 & 11 & 0.180 & 12 & 0.183 & 12 & 0.179 & 12 & 0.177 & 13 & 0.163 & 17 & 0.146 & 22 \\
\hline Denmark & 0.347 & 4 & 0.349 & 4 & 0.344 & 4 & 0.353 & 4 & 0.383 & 4 & 0.407 & 4 & 0.403 & 4 & 0.383 & 4 \\
\hline Finland & 0.413 & 3 & 0.501 & 2 & 0.561 & 2 & 0.557 & 2 & 0.482 & 2 & 0.547 & 2 & 0.548 & 2 & 0.487 & 2 \\
\hline France & 0.189 & 12 & 0.180 & 13 & 0.166 & 13 & 0.169 & 14 & 0.175 & 14 & 0.177 & 14 & 0.169 & 14 & 0.147 & 20 \\
\hline Germany & 0.280 & 6 & 0.267 & 6 & 0.250 & 6 & 0.251 & 7 & 0.254 & 6 & 0.258 & 6 & 0.259 & 6 & 0.246 & 6 \\
\hline Greece & 0.113 & 22 & 0.139 & 20 & 0.136 & 20 & 0.137 & 20 & 0.135 & 21 & 0.151 & 19 & 0.138 & 20 & 0.158 & 17 \\
\hline Hungary & 0.119 & 20 & 0.117 & 22 & 0.101 & 23 & 0.105 & 25 & 0.106 & 25 & 0.100 & 25 & 0.088 & 26 & 0.085 & 25 \\
\hline Ireland & 0.111 & 23 & 0.110 & 23 & 0.103 & 22 & 0.109 & 24 & 0.108 & 24 & 0.126 & 23 & 0.124 & 23 & 0.128 & 23 \\
\hline Italy & 0.257 & 7 & 0.252 & 7 & 0.234 & 7 & 0.240 & 8 & 0.238 & 8 & 0.238 & 8 & 0.219 & 10 & 0.201 & 10 \\
\hline Latvia & 0.299 & 5 & 0.303 & 5 & 0.309 & 5 & 0.305 & 5 & 0.296 & 5 & 0.312 & 5 & 0.310 & 5 & 0.276 & 5 \\
\hline Lithuania & 0.160 & 16 & 0.161 & 15 & 0.159 & 15 & 0.190 & 11 & 0.188 & 11 & 0.198 & 11 & 0.187 & 11 & 0.154 & 18 \\
\hline Malta & 0.042 & 28 & 0.045 & 28 & 0.053 & 28 & 0.057 & 28 & 0.071 & 28 & 0.087 & 26 & 0.088 & 27 & 0.081 & 26 \\
\hline Netherlands & 0.118 & 21 & 0.105 & 24 & 0.099 & 24 & 0.116 & 22 & 0.137 & 20 & 0.155 & 18 & 0.170 & 13 & 0.176 & 12 \\
\hline Poland & 0.109 & 24 & 0.100 & 25 & 0.086 & 25 & 0.085 & 26 & 0.077 & 27 & 0.076 & 28 & 0.072 & 28 & 0.067 & 28 \\
\hline Portugal & 0.186 & 13 & 0.185 & 12 & 0.233 & 8 & 0.252 & 6 & 0.252 & 7 & 0.253 & 7 & 0.240 & 8 & 0.207 & 9 \\
\hline Romania & 0.141 & 18 & 0.142 & 19 & 0.142 & 18 & 0.148 & 17 & 0.148 & 19 & 0.146 & 21 & 0.128 & 22 & 0.173 & 13 \\
\hline Slovakia & 0.123 & 19 & 0.121 & 21 & 0.125 & 21 & 0.134 & 21 & 0.127 & 22 & 0.119 & 24 & 0.106 & 25 & 0.116 & 24 \\
\hline Slovenia & 0.207 & 9 & 0.208 & 8 & 0.183 & 11 & 0.180 & 13 & 0.171 & 15 & 0.177 & 15 & 0.174 & 12 & 0.163 & 15 \\
\hline Spain & 0.165 & 14 & 0.160 & 16 & 0.157 & 16 & 0.156 & 16 & 0.178 & 13 & 0.180 & 12 & 0.164 & 15 & 0.159 & 16 \\
\hline Sweden & 0.693 & 1 & 0.679 & 1 & 0.658 & 1 & 0.678 & 1 & 0.700 & 1 & 0.698 & 1 & 0.691 & 1 & 0.653 & 1 \\
\hline United Kingdom & 0.070 & 26 & 0.074 & 26 & 0.081 & 26 & 0.110 & 23 & 0.123 & 23 & 0.129 & 22 & 0.133 & 21 & 0.154 & 19 \\
\hline
\end{tabular}


Table A3. The $\tau$-Kendall's correlation coefficients calculated for EU countries ranks according to taxonomic measure of development.

\begin{tabular}{|c|c|c|c|c|c|c|c|c|c|c|c|c|c|c|c|c|}
\hline Year & 2004 & 2005 & 2006 & 2007 & 2008 & 2009 & 2010 & 2011 & 2012 & 2013 & 2014 & 2015 & 2016 & 2017 & 2018 & 2019 \\
\hline 2004 & 1.000 & 0.990 & 0.979 & 0.952 & 0.916 & 0.910 & 0.896 & 0.883 & 0.893 & 0.918 & 0.920 & 0.916 & 0.894 & 0.876 & 0.865 & 0.833 \\
\hline 2005 & 0.990 & 1.000 & 0.987 & 0.968 & 0.948 & 0.940 & 0.914 & 0.891 & 0.898 & 0.909 & 0.911 & 0.905 & 0.891 & 0.877 & 0.876 & 0.835 \\
\hline 2006 & 0.979 & 0.987 & 1.000 & 0.985 & 0.955 & 0.942 & 0.909 & 0.889 & 0.897 & 0.915 & 0.923 & 0.926 & 0.908 & 0.899 & 0.897 & 0.851 \\
\hline 2008 & 0.916 & 0.948 & 0.955 & 0.972 & 1.000 & 0.980 & 0.932 & 0.884 & 0.897 & 0.881 & 0.893 & 0.892 & 0.891 & 0.891 & 0.885 & 0.814 \\
\hline 2009 & 0.910 & 0.940 & 0.942 & 0.966 & 0.980 & 1.000 & 0.977 & 0.935 & 0.937 & 0.906 & 0.920 & 0.909 & 0.921 & 0.924 & 0.909 & 0.817 \\
\hline 2010 & 0.896 & 0.914 & 0.909 & 0.932 & 0.932 & 0.977 & 1.000 & 0.958 & 0.961 & 0.930 & 0.940 & 0.913 & 0.926 & 0.922 & 0.888 & 0.787 \\
\hline 2011 & 0.883 & 0.891 & 0.889 & 0.912 & 0.884 & 0.935 & 0.958 & 1.000 & 0.958 & 0.930 & 0.933 & 0.912 & 0.919 & 0.909 & 0.891 & 0.818 \\
\hline 2013 & 0.918 & 0.909 & 0.915 & 0.924 & 0.881 & 0.906 & 0.930 & 0.930 & 0.973 & 1.000 & 0.992 & 0.968 & 0.959 & 0.943 & 0.914 & 0.839 \\
\hline 2014 & 0.920 & 0.911 & 0.923 & 0.933 & 0.893 & 0.920 & 0.940 & 0.933 & 0.967 & 0.992 & 1.000 & 0.984 & 0.975 & 0.959 & 0.925 & 0.856 \\
\hline 2015 & 0.916 & 0.905 & 0.926 & 0.924 & 0.892 & 0.909 & 0.913 & 0.912 & 0.939 & 0.968 & 0.984 & 1.000 & 0.991 & 0.977 & 0.949 & 0.883 \\
\hline 2016 & 0.894 & 0.891 & 0.908 & 0.914 & 0.891 & 0.921 & 0.926 & 0.919 & 0.940 & 0.959 & 0.975 & 0.991 & 1.000 & 0.992 & 0.964 & 0.884 \\
\hline 2017 & 0.876 & 0.877 & 0.899 & 0.909 & 0.891 & 0.924 & 0.922 & 0.909 & 0.930 & 0.943 & 0.959 & 0.977 & 0.992 & 1.000 & 0.976 & 0.887 \\
\hline 2018 & 0.865 & 0.876 & 0.897 & 0.904 & 0.885 & 0.909 & 0.888 & 0.891 & 0.900 & 0.914 & 0.925 & 0.949 & 0.964 & 0.976 & 1.000 & 0.915 \\
\hline 2019 & 0.833 & 0.835 & 0.851 & 0.857 & 0.814 & 0.817 & 0.787 & 0.818 & 0.793 & 0.839 & 0.856 & 0.883 & 0.884 & 0.887 & 0.915 & 1.000 \\
\hline
\end{tabular}




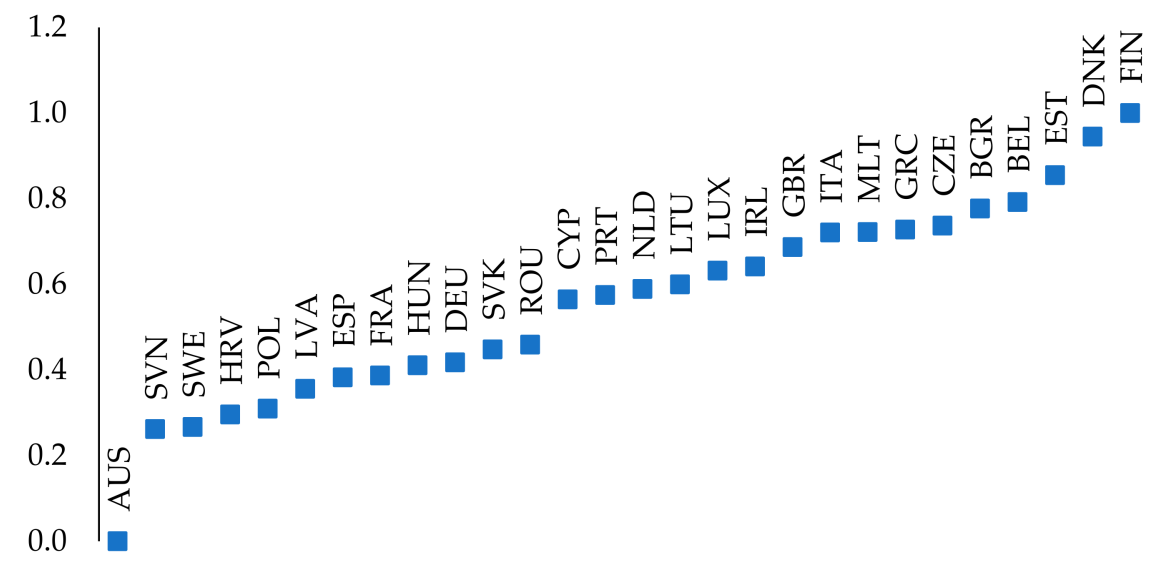

Figure A1. Linear ordering of the EU countries on the basis of coefficients of linear trends.

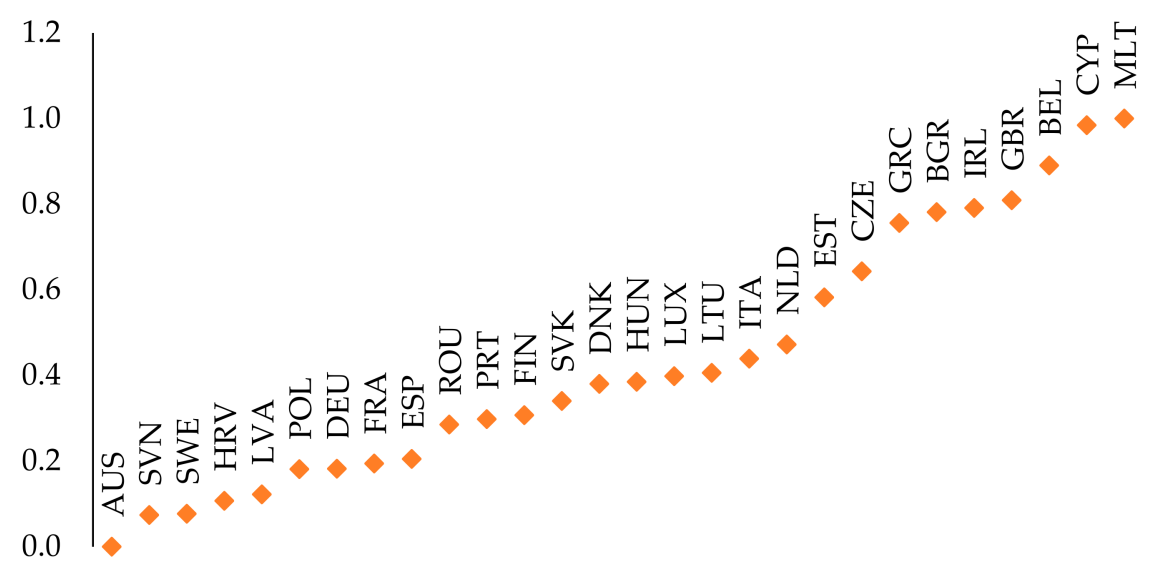

Figure A2. Linear ordering of the EU countries on the basis of coefficients of exponential trends.

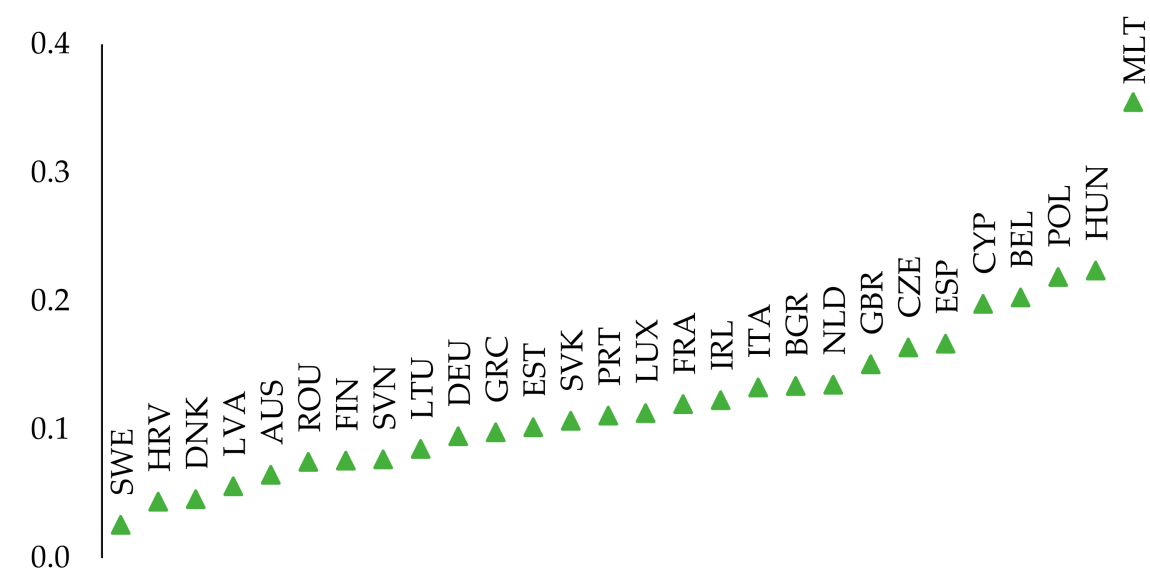

Figure A3. Linear ordering of the EU countries on the basis of the random variation coefficient determined on the basis of linear trends. 


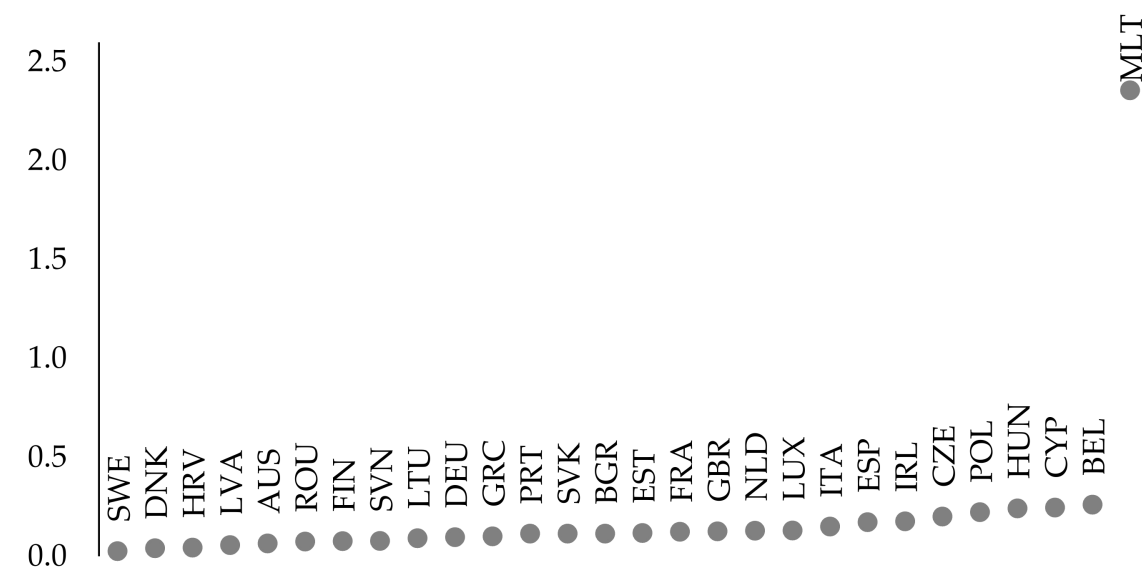

Figure A4. Linear ordering of the EU countries on the basis of the random variation coefficient determined on the basis of exponential trends.

\section{References}

1. Sikora, A. European Green Deal-Legal and financial challenges of the climate change. In ERA Forum; Springer: Berlin/Heidelberg, Germany, 2021; Volume 21, pp. 681-697. [CrossRef]

2. Ziolo, M.; Jednak, S.; Savić, G.; Kragulj, D. Link between Energy Efficiency and Sustainable Economic and Financial Development in OECD Countries. Energies 2020, 13, 5898. [CrossRef]

3. Lucchi, E.; Polo Lopez, C.S.; Franco, G. A conceptual framework on the integration of solar energy systems in heritage sites and buildings. In IOP Conference Series: Materials Science and Engineering, Proceedings of the International Conference Florence Heri-Tech: The Future of Heritage Science and Technologies, Online, 14-16 October 2020; IOP Publishing: Bristol, UK, 2020; Volume 949.

4. Sánchez-Pantoja, N.; Vidal, R.; Pastor, M. EU-Funded Projects with Actual Implementation of Renewable Energies in Cities. Analysis of Their Concern for Aesthetic Impact. Energies 2021, 14, 1627. [CrossRef]

5. Temiz, D.; Gokmen, A. The importance of renewable energy sources in turkey. Int. J. Econ. Fin. Stud. 2010, 2, 22-30.

6. Panwar, N.; Kaushik, S.; Kothari, S. Role of renewable energy sources in environmental protection: A review. Renew. Sustain. Energy Rev. 2011, 15, 1513-1524. [CrossRef]

7. Abolhosseini, S.; Heshmati, A.; Altmann, J. A Review of Renewable Energy Supply and Energy Efficiency Technologies. IZA Discuss. Pap. 2014, No. 8145. Available online: http:/ / ftp.iza.org/dp8145.pdf (accessed on 30 June 2021).

8. Samarina, V.; Skufina, T.; Samarin, A.; Ushakov, D. Alternative Energy Sources: Opportunities, Experience and Prospects of the Russian Regions in the Context of Global Trends. Inter. J. Ener. Econ. Policy 2018, 8, 140-147.

9. Razmjoo, A.A.; Davarpanah, A.; Zargarian, A. The Role of Renewable Energy to Achieve Energy Sustainability in Iran. An Economic and Technical Analysis of the Hybrid Power System. Technol. Econ. Smart Grids Sustain. Energy 2019, 4, 7. [CrossRef]

10. UNCTAD. The Role of Science, Technology and Innovation in Promoting Renewable Energy by 2030; United Nations: Geneva, Switzerland, 2019.

11. Marks-Bielska, R.; Bielski, S.; Pik, K.; Kurowska, K. The Importance of Renewable Energy Sources in Poland's Energy Mix. Energies 2020, 13, 4624. [CrossRef]

12. Owusu, P.A.; Asumadu-Sarkodie, S. A review of renewable energy sources, sustainability issues and climate change mitigation. Cogent Eng. 2016, 3, 1167990. [CrossRef]

13. Abbasi, T.; Premalatha, M.; Abbasi, S. The return to renewables: Will it help in global warming control? Renew. Sustain. Energy Rev. 2011, 15, 891-894. [CrossRef]

14. Lu, Y.; Nakicenovic, N.; Visbeck, M.; Stevance, A.-S. Policy: Five priorities for the UN Sustainable Development Goals. Nat. Cell Biol. 2015, 520, 432-433. [CrossRef]

15. Koroneos, C.; Spachos, T.; Moussiopoulos, N. Exergy analysis of renewable energy sources. Renew. Energy 2003, 28, 295-310. [CrossRef]

16. Hansen, C.; Skinner, R. Nuclear Power and Renewables: Strange Bedfellows? Oxford Energy Comment, 2005. Oxford Institute for Energy Studies. Available online: https:/ / www.oxfordenergy.org/wpcms/wp-content/uploads/2011/01/July2005NuclearPowerandRenewables-ChristopherHansenandRobertSkinner.pdf (accessed on 5 May 2021).

17. Gielen, D.; Boshell, F; Saygin, D.; Bazilian, M.D.; Wagner, N.; Gorini, R. The role of renewable energy in the global energy transformation. Energy Strategy Rev. 2019, 24, 38-50. [CrossRef]

18. Noorollahi, Y.; Pourarshad, M.; Veisi, A. The synergy of Renewable Energies for Sustainable Energy Systems Development in Oil-Rich Nations; Case of Iran. Renew. Energy 2021, 173, 561-568. [CrossRef]

19. Elum, Z.; Momodu, A.S. Climate change mitigation and renewable energy for sustainable development in Nigeria: A discourse approach. Renew. Sustain. Energy Rev. 2017, 76, 72-80. [CrossRef] 
20. Ziolo, M.; Kluza, K.; Spoz, A. Impact of Sustainable Financial and Economic Development on Greenhouse Gas Emission in the Developed and Converging Economies. Energies 2019, 12, 4514. [CrossRef]

21. Kulovesi, K.; Oberthür, S. Assessing the EU's 2030 Climate and Energy Policy Framework: Incremental change toward radical transformation? Rev. Eur. Comp. Int. Environ. Law 2020, 29, 151-166. [CrossRef]

22. Wang, Q.; Zhan, L. Assessing the sustainability of renewable energy by combining 3E model and RAGA-PP techniques: An empirical analysis of selected 18 European countries. Sci. Total Environ. 2019. [CrossRef]

23. Jenniches, S. Assessing the regional economic impacts of renewable energy sources-A literature review. Renew. Sustain. Energy Rev. 2018, 93, 35-51. [CrossRef]

24. Li, T.; Li, A.; Guo, X. The sustainable development-oriented development and utilization of renewable energy industry-A comprehensive analysis of MCDM methods. Energy 2020, 212, 118694. [CrossRef]

25. Statistics Poland. 2019. Available online: https://bdl.stat.gov.pl/BDL/metadane/cechy/1674?back=True\# (accessed on 7 May 2021).

26. Solangi, Y.A.; Longsheng, C.; Shah, S.A.A. Assessing and overcoming the renewable energy barriers for sustainable development in Pakistan: An integrated AHP and fuzzy TOPSIS approach. Renew. Energy 2021, 173, 209-222. [CrossRef]

27. Ogunlana, A.O.; Goryunova, N.N. Tax Incentives for Renewable Energy: The European Experience. Eur. Proc. Soc. Behav. Sci. 2017, 19, 507-513. [CrossRef]

28. Lezama, J.M.L.; Villada, F.; Galeano, N.M. Effects of Incentives for Renewable Energy in Colombia. Ing. Univ. 2017, 21, 257-272. [CrossRef]

29. Simsek, H.A.; Simsek, N. Recent incentives for renewable energy in Turkey. Energy Policy 2013, 63, 521-530. [CrossRef]

30. U.S. Energy Information Administration. Renewable Energy; EIA: Washington, DC, USA, 2018. Available online: https://www.eia. gov/energyexplained/renewable-sources/ (accessed on 6 May 2021).

31. Pan, X.; Wang, Y. Evaluation of renewable energy sources in China using an interval type-2 fuzzy large-scale group risk evaluation method. Appl. Soft Comput. 2021, 108, 107458. [CrossRef]

32. John, A.; Basu, S.; Kumar, A. Design and evaluation of stand-alone solar-hydrogen energy storage system for academic institute: A case study. Mater. Today Proc. 2021. [CrossRef]

33. Cousse, J. Still in love with solar energy? Installation size, affect, and the social acceptance of renewable energy technologies. Renew. Sust. Energy Rev. 2021, 145, 111107. [CrossRef]

34. Chiemelu, N.E.; Anejionu, O.C.; Ndukwu, R.I.; Okeke, F.I. Assessing the potentials of largescale generation of solar energy in Eastern Nigeria with geospatial technologies. Sci. Afr. 2021, 12, e00771. [CrossRef]

35. Yao, Y.; Xu, J.-H.; Sun, D.-Q. Untangling global levelised cost of electricity based on multi-factor learning curve for renewable energy: Wind, solar, geothermal, hydropower and bioenergy. J. Clean. Prod. 2021, 285, 124827. [CrossRef]

36. Stefano, F.; Valentina, G.; Roberto, B.; Vito, L.; Riccardo, G. Setting up of a cost-effective continuous desalination plant based on coupling solar and geothermal energy. Desalination 2021, 500, 114854. [CrossRef]

37. Hamzaoğlu, A.; Erduman, A.; Alçı, M. Reduction of distribution system losses using solar energy cooperativity by home user. Ain Shams Eng. J. 2021. [CrossRef]

38. Anctil, A.; Lee, E.; Lunt, R.R. Net energy and cost benefit of transparent organic solar cells in building-integrated applications. Appl. Energy 2020, 261, 114429. [CrossRef]

39. Sultan, M.; Wu, J.; Aleem, F.E.; Imran, M. Cost and energy analysis of a grid-tie solar system synchronized with utility and fossil fuel generation with major Issues for the attenuation of solar power in Pakistan. Sol. Energy 2018, 174, 967-975. [CrossRef]

40. Novacheck, J.; Johnson, J.X. The environmental and cost implications of solar energy preferences in Renewable Portfolio Standards. Energy Policy 2015, 86, 250-261. [CrossRef]

41. Shahsavari, A.; Akbari, M. Potential of solar energy in developing countries for reducing energy-related emissions. Renew. Sustain. Energy Rev. 2018, 90, 275-291. [CrossRef]

42. Creutzig, F.; Agoston, P.; Goldschmidt, J.C.; Luderer, G.; Nemet, G.; Pietzcker, R.C. The underestimated potential of solar energy to mitigate climate change. Nat. Energy 2017, 2, 17140. [CrossRef]

43. Ambec, S.; Crampes, C. Decarbonizing Electricity Generation with Intermittent Sources of Energy. J. Assoc. Environ. Resour. Econ. 2019, 6, 1105-1134. [CrossRef]

44. Adeyeye, K.; Ijumba, N.; Colton, J. Exploring the environmental and economic impacts of wind energy: A cost-benefit perspective. Int. J. Sustain. Dev. World Ecol. 2020, 27, 718-731. [CrossRef]

45. Sayed, E.T.; Wilberforce, T.; Elsaid, K.; Rabaia, M.K.H.; Abdelkareem, M.A.; Chae, K.-J.; Olabi, A. A critical review on environmental impacts of renewable energy systems and mitigation strategies: Wind, hydro, biomass and geothermal. Sci. Total Environ. 2021, 766, 144505. [CrossRef]

46. Wellig, S.D.; Nusslé, S.; Miltner, D.; Kohle, O.; Glaizot, O.; Braunisch, V.; Obrist, M.K.; Arlettaz, R. Mitigating the negative impacts of tall wind turbines on bats: Vertical activity profiles and relationships to wind speed. PLoS ONE 2018, 13, e0192493. [CrossRef]

47. Diógenes, J.R.F.; Claro, J.; Rodrigues, J.C.; Loureiro, M.V. Barriers to onshore wind energy implementation: A systematic review. Energy Res. Soc. Sci. 2020, 60, 101337. [CrossRef]

48. Gönül, Ö.; Duman, A.C.; Deveci, K.; Güler, Ö. An assessment of wind energy status, incentive mechanisms and market in Turkey. Eng. Sci. Technol. Int. J. 2021. [CrossRef] 
49. Aldy, J.; Gerarden, T.; Sweeney, R. Investment versus Output Subsidies: Implications of Alternative Incentives for Wind. Energy 2018. [CrossRef]

50. Black, G.; Holley, D.; Solan, D.; Bergloff, M. Fiscal and economic impacts of state incentives for wind energy development in the Western United States. Renew. Sustain. Energy Rev. 2014, 34, 136-144. [CrossRef]

51. Javed, M.S.; Ma, T.; Jurasz, J.; Amin, M.Y. Solar and wind power generation systems with pumped hydro storage: Review and future perspectives. Renew. Energy 2020, 148, 176-192. [CrossRef]

52. Fan, J.; Xie, H.; Chen, J.; Jiang, D.; Li, C.; Tiedeu, W.N.; Ambre, J. Preliminary feasibility analysis of a hybrid pumped-hydro energy storage system using abandoned coal mine goafs. Appl. Energy 2020, 258, 114007. [CrossRef]

53. Lu, Z.; Gao, Y.; Zhao, W. A TODIM-based approach for environmental impact assessment of pumped hydro energy storage plant J. Clean. Prod. 2020, 248, 119265. [CrossRef]

54. Penghao, C.; Pingkuo, L.; Hua, P. Prospects of hydropower industry in the Yangtze River Basin: China's green energy choice. Renew. Energy 2019, 131, 1168-1185. [CrossRef]

55. Yang, C.-J.; Jackson, R.B. Opportunities and barriers to pumped-hydro energy storage in the United States. Renew. Sustain. Energy Rev. 2011, 15, 839-844. [CrossRef]

56. Ciric, R.M. Review of techno-economic and environmental aspects of building small hydro electric plants-A case study in Serbia. Renew. Energy 2019, 140, 715-721. [CrossRef]

57. Paulillo, A.; Striolo, A.; Lettieri, P. The environmental impacts and the carbon intensity of geothermal energy: A case study on the Hellisheiði plant. Environ. Int. 2019, 133, 105226. [CrossRef]

58. Bošnjakovid, M.; Stojkov, M.; Jurjevid, M. Environmental impact of geothermal power plants. Teh. Vjesn. 2019, $26,1515-1522$.

59. Shortall, R.; Davidsdottir, B.; Axelsson, G. Geothermal energy for sustainable development: A review of sustainability impacts and assessment frameworks. Renew. Sustain. Energy Rev. 2020, 44, 391-406. [CrossRef]

60. Yasukawa, K.; Lee, T.J.; Uchida, T.; Song, Y. Environmental Barriers to Geothermal Development in Eastern and South-Eastern Asia. In Proceedings of the World Geothermal Congress 2020, Online. 21-26 May 2021.

61. Danish, R.; Ulucak, R. Linking biomass energy and $\mathrm{CO}_{2}$ emissions in China using dynamic Autoregressive-Distributed Lag simulations. J. Clean. Prod. 2020, 250, 119533. [CrossRef]

62. Güney, T.; Kantar, K. Biomass energy consumption and sustainable development. Int. J. Sustain. Dev. World Ecol. 2020, 27, 762-767. [CrossRef]

63. Chang, W.-R.; Hwang, J.-J.; Wu, W. Environmental impact and sustainability study on biofuels for transportation applications. Renew. Sust. Energ. Rev. 2017, 67, 277-288. [CrossRef]

64. Inayat, A.; Nassef, A.M.; Rezk, H.; Sayed, E.T.; Abdelkareem, M.A.; Olabi, A.G. Fuzzy modeling and parameters optimization for the enhancement of biodiesel production from waste frying oil over montmorillonite clay K-30. Sci. Total Environ. 2019, 666, 821-827. [CrossRef]

65. Mohamed, H.O.; Obaid, M.; Sayed, E.T.; Abdelkareem, M.A.; Park, M.; Liu, Y.; Kim, H.-Y.; Barakat, N.A.M. Graphite Sheets as High-Performance Low-Cost Anodes for Microbial Fuel Cells Using Real Food Wastewater. Chem. Eng. Technol. 2017, 40, 2243-2250. [CrossRef]

66. Qazi, A.; Hussain, F.; Rahim, N.A.; Hardaker, G.; Alghazzawi, D.; Shaban, K.; Haruna, K. Towards Sustainable Energy: A Systematic Review of Renewable Energy Sources, Technologies, and Public Opinions. IEEE Access 2019, 7, 63837-63851. [CrossRef]

67. Yang, Y.; Solgaard, H.S.; Haider, W. Wind, hydro or mixed renewable energy source: Preference for electricity products when the share of renewable energy increases. Energy Policy 2016, 97, 521-531. [CrossRef]

68. Nermend, K. Taxonomic Vector Measure of Region Development (TWMRR). Pol. J. Environ. Stud. 2017, 16, 195-198.

69. Roszkowska, E.; Filipowicz-Chomko, M. Measuring Sustainable Development Using an Extended Hellwig Method: A Case Study of Education. Soc. Indic. Res. 2021, 153, 299-322. [CrossRef]

70. Pawlas, I. Economic Picture of the Enlarged European Union in the Light of Taxonomic Research. In Proceedings of the MAC-EMM 2016, Prague, Czech Republic, 5-6 August 2016.

71. Reiff, M.; Surmanová, K.; Balcerzak, A.P.; Pietrzak, M.B. Multiple Criteria Analysis of European Union Agriculture. J. Int. Stud. 2016, 9, 62-74. [CrossRef]

72. Kukuła, K. Metoda Unitaryzacji Zerowanej; PWN: Warszawa, Poland, 2000.

73. Bak, I.; Cheba, K. An analysis of dynamic changes in selected areas of sustainable development of the European Union countries. Folia Oeconomica Stetin. 2018, 18, 93-107. [CrossRef]

74. Bak, I.; Cheba, K. The application of the dynamic classifications in order to evaluate the changes of the European Union's Sustainable Development. In Proceedings of the 2018 International Conference "Economic Science for Rural Development", Jelgava, Latvia, 9-11 May 2018; pp. 36-43.

75. Grabiński, T. Wybrane problemy dynamicznej wielowymiarowej analizy porównawczej. Ruch Praw. Ekon. Socjol. 1985, 2, 189-206.

76. Nowak, E. Metody Taksonomiczne w Klasyfikacji Obiektów Społeczno-Gospodarczych; Państwowe Wydawnictwo Ekonomiczne: Warszawa, Poland, 1990.

77. Steczkowski, J.; Zeliaś, A. Metody Statystyczne w Badaniu Zjawisk Jakościowych; Wydawnictwo Uczelniane Akademii Ekonomicznej w Krakowie: Kraków, Poland, 1997. 
78. Stanisz, A. Przystepny Kurs Statystyki z Zastosowaniem STATISTICA PL na Przykładach z Medycyny, t. 1. Statystyki Podstawowe; Wydawnictwo StatSoft Polska: Kraków, Poland, 2006.

79. Global Trends in Renewable Energy Investment. BloombergNEF, United Nations Environment Programme, Frankfurt am Main. 2020. Available online: http:/ / www.fs-unep-centre.org (accessed on 30 June 2021).

80. Hess, D.J.; McKane, R.G. Renewable Energy Research and Development: A Political Economy Perspective. In Routledge Handbook of the Political Economy of Science; Tyfield, D., Lave, R., Randalls, S., Thorpe, C., Eds.; Routledge: London, UK, 2016.

81. Burke, M.J.; Stephens, J. Political power and renewable energy futures: A critical review. Energy Res. Soc. Sci. 2018, 35, 78-93. [CrossRef]

82. Pegels, A.; Vidican-Auktor, G.; Lütkenhorst, W.; Altenburg, T. Politics of Green Energy Policy. J. Environ. Dev. 2018, 27, 26-45. [CrossRef]

83. Heffron, R.J.; Talus, K. The development of energy law in the 21st century: A paradigm shift? J. World Energy Law Bus. 2016, 9 , 189-202. [CrossRef]

84. O'Sullivan, M.; Overland, I.; Sandalow, D. The Geopolitics of Renewable Energy Center on Global Energy Policy; Columbia University: New York, NY, USA, 2017.

85. Heffron, R.J.; Rønne, A.; Tomain, J.P.; Bradbrook, A.; Talus, K. A treatise for energy law. J. World Energy Law Bus. 2018, 11, 34-48. [CrossRef]

86. Turney, D.; Fthenakis, V. Environmental impacts from the installation and operation of large-scale solar powerplants. Renew. Sustain. Energy 2011, 15, 3261-3270. [CrossRef]

87. Kumar, M. Social, Economic, and Environmental Impacts of Renewable Energy Resources. In Wind Solar Hybrid Renewable Energy System; Okedu, K.E., Tahour, A., Aissaou, A.G., Eds.; IntechOpen: London, UK, 2020; Chapter 11; Available online: https:/ / www.intechopen.com/books/wind-solar-hybrid-renewable-energy-system/social-economic-and-environmentalimpacts-of-renewable-energy-resources (accessed on 30 June 2021). [CrossRef]

88. Mizobuchi, K.; Takeuchi, K. The influences of financial and non-financial factors on energy-saving behaviour: A field experiment in Japan. Energy Policy 2013, 63, 775-787. [CrossRef]

89. Peimani, H. Financial Barriers to Development of Renewable and Green Energy Projects in Asia. ADBI Working Paper 862. 2018. Available online: https:/ / www.adb.org/publications/financial-barriers-development-renewable-green-energy-projects-asia (accessed on 30 June 2021).

90. Le, H.P. The energy-growth nexus revisited: The role offinancial development, institutions, government expenditure and trade openness. Heliyon 2020, 6, e04369. [CrossRef] [PubMed]

91. An Official Website of the European Union. Available online: https://europa.eu/european-union/topics/environment_pl (accessed on 7 January 2021).

92. Ossowska, L.; Janiszewska, D.; Bartkowiak-Bakun, N.; Kwiatkowski, G. Energy Consumption Versus Greenhouse Gas Emissions in EU. Eur. Res. Stud. J. 2020, XXIII, 185-198. [CrossRef]

93. Standar, A.; Kozera, A.; Satoła, Ł. The Importance of Local Investments Co-Financed by the European Union in the Field of Renewable Energy Sources in Rural Areas of Poland. Energies 2021, 14, 450. [CrossRef]

94. Aceleanu, M.; Șerban, A.C.; Pociovălișteanu, D.M.; Dimian, G.C. Renewable energy: A way for a sustainable development in Romania. Energy Sources Part B Econ. Plan. Policy 2017, 12, 958-963. [CrossRef]

95. Akar, B.G. The Determinants of Renewable Energy Consumption: An Empirical Analysis for The Balkans. Eur. Sci. J. ESJ 2016, 12, 594-607. [CrossRef]

96. Spaiser, V.; Ranganathan, S.; Swain, R.B.; Sumpter, D.J.T. The sustainable development oxymoron: Quantifying and modelling the incompatibility of sustainable development goals. Int. J. Sustain. Dev. World Ecol. 2017, 24, 457-470. [CrossRef]

97. Wu, G.; Liu, D.; Yan, Y. Sustainable development and ecological protection associated with coal-fired power plants in China. Int. J. Sustain. Dev. World Ecol. 2017, 24, 385-388. [CrossRef]

98. United Nations. Sustainable Development Goals. 2019. Available online: https://www.un.org/sustainabledevelopment/energy/ (accessed on 30 June 2021).

99. Streimikiene, D.; Klevas, V.; Bubeliene, J. Use of EU structural funds for sustainable energy development in new EU member states. Renew. Sustain. Energy Rev. 2007, 11, 1167-1187. [CrossRef]

100. Bointner, R.; Pezzutto, S.; Grilli, G.; Sparber, W. Financing innovations for the renewable energy transition in Europe. Energies 2016, 9, 990. [CrossRef]

101. Carfora, A.; Romano, A.A.; Ronghi, M.; Scandurra, G. Renewable generation across Italian regions: Spillover effects and effectiveness of European Regional Fund. Energy Policy 2017, 102, 132-141. [CrossRef]

102. Bostan, I.; Lazar, C.M.; Asalos, N.; Munteanu, I.; Horga, G.M. The three-dimensional impact of the absorption effects of European funds on the competitiveness of the SMEs from the Danube Delta. Ind. Crops Prod. 2019, 132, 460-467. [CrossRef]

103. Kazak, J.K.; Kamiń, J.A.; Madej, R.; Bochenkiewicz, M. Where Renewable Energy Sources Funds are Invested? Spatial Analysis of Energy Production Potential and Public Support. Energies 2020, 13, 5551. [CrossRef]

104. Nurkan, K.A. The Impact of Government Policies in the Renewable Energy Investment: Developing a Conceptual Framework and Qualitative Analysis. Glob. Adv. Res. J. Manag. Bus. Stud. 2015, 4, 67-81.

105. May, N.; Neuhoff, K. Financing Power: Impacts of Energy Policies in Changing Regulatory Environments. DIW Berl. Discuss. Pap. 2017, 1684. Available online: https:/ / ssrn.com/abstract=3046516 (accessed on 30 June 2021). [CrossRef] 
106. Layke, J.; Hutchinson, N. 3 Reasons to Invest in Renewable Energy Now. World Resources Institute, 2020. Available online: https:/ / www.wri.org/insights/3-reasons-invest-renewable-energy-now (accessed on 4 May 2021).

107. Newbery, D. Policies for decarbonizing a liberalized power sector. Econ. Open-Access Open-Assess. E-J. 2018, 12, 1-24. [CrossRef] 